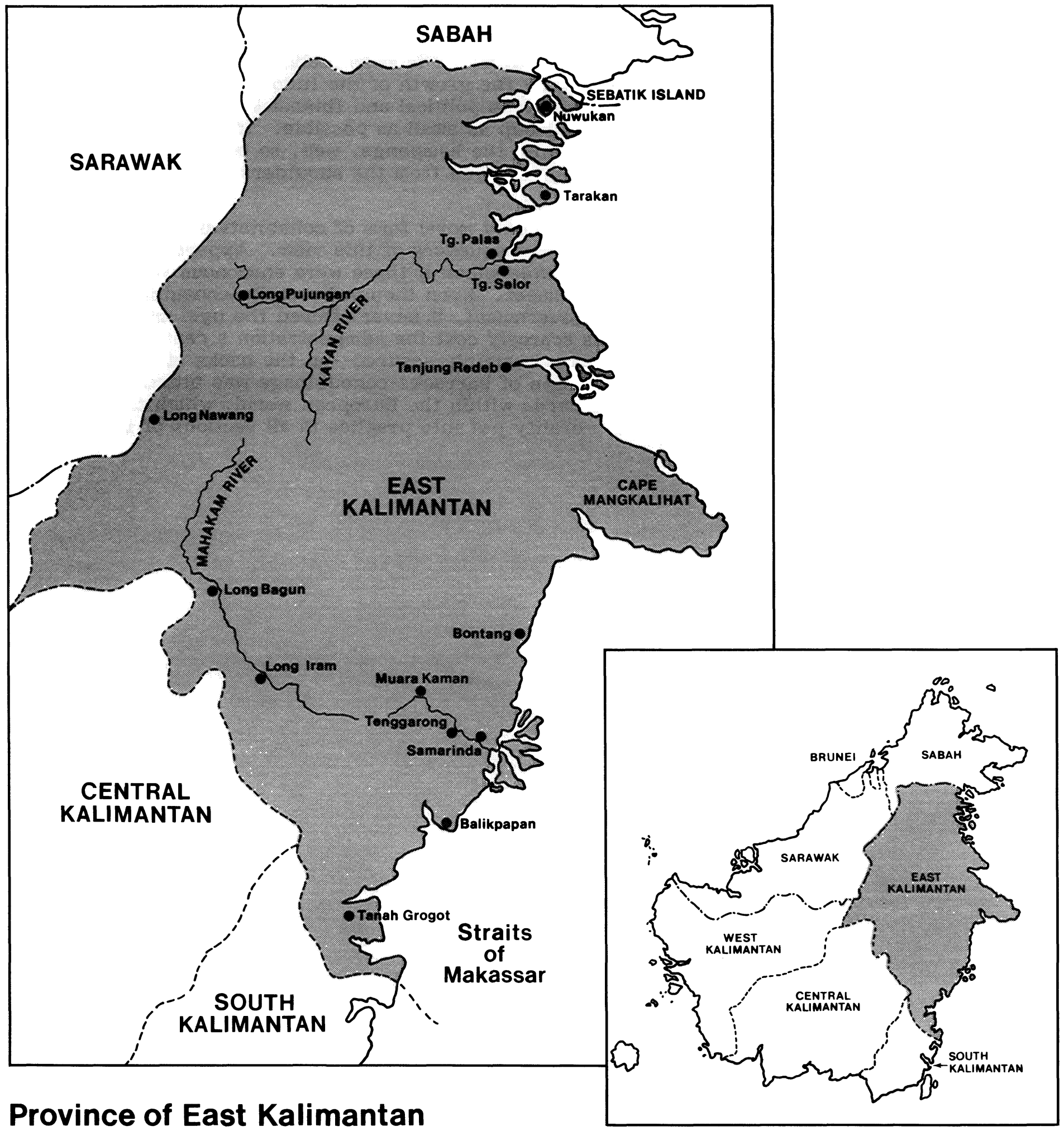




\title{
NETWORKING IN THE COMMONS: A TRAGEDY FOR RATTAN?
}

\author{
Nancy Lee Peluso
}

\begin{abstract}
The more accessible canes are rapidly becoming exhausted, not only from the destruction of the forests to make way for agriculture, but because of the failure of regeneration to keep pace with collection . . . the buyers, who are almost invariably small Chinese shopkeepers, cannot afford to be too particular, for they do not care to risk losing the advances in goods or cash that they have had to make to the collectors. ${ }^{1}$
\end{abstract}

Although written nearly fifty years ago, the above passage expresses fears that are still current among Indonesian foresters, exporters, and government officials today concerning an important forest product: rattan. The world demand for rattan, the spiny climby palms of the Lepidocaryeae subfamily of the family Palmae, also known as cane or wicker, is increasing rapidly, and Indonesia produces between $76^{2}$ and 90 percent ${ }^{3}$ of the world's supply. Indonesian exports increased at least 200 percent in the ten-year period from 1968 to $1977,{ }^{4}$ with rattan generating more foreign exchange for Indonesia than any other forest product except logs. ${ }^{5}$ Nearly half of these rattan exports come from Kalimantan (Indonesian Borneo), with the largest production area for both wild and cultivated varieties--approximately $4,375,000$ hectares--being the province of East Kalimantan. ${ }^{6}$

1. J. H. Burkill, A Dictionary of the Economic Products of the Malay Peninsula (1935; Kuala Lumpur: Government of Malaysia and Singapore, 1966), pp. 1904-5.

2. "Industrialisasi Rotan di Indonesia," Kehutanan Indonesia [Jakarta], 6, no. 7 (July 1979), pp. 17-29.

3. K. E. Menon, "Rattan in the South East Asian Region," Forest News for Asia and the Pacific [Bangkok], 2, no. 4 (November 1978), pp. 32-35.

4. Badan Penelitian dan Pengembangan Industri Departemen Industri, "Pengembangan Industri Komodite Export Rotan di Indonesia Didasarkan Pada Teknology Tepat" (Paper presented to Discussion of Increasing Production Potential of Nontimber Forest Products, Jakarta, July 10-12, 1980), p. 7a.

5. Djwa Hui Liang, "Beberapa Pendekatan Dalam Usaha Pelestarian Rotan," typed manuscript (South Kalimantan: Dinas Kehutanan Propinsi DATI I, November 1979), p. 1 .

6. Chaiyapechara, "Rattan," Forest News for Asia and the Pacific, 2, no. 4 (November 1978), p. 38. Most of the data on the natural history of rattan were provided by Dr. John Dransfield of Kew Gardens, Surrey, England. In a personal communication (1982) Dr. Dransfield described the distribution of rattan in Southeast Asia as "a dartboard with the bull's-eye in Malaysia." 
Recently the riverine and land networks through which rattan is traded have expanded dramatically. As a result, collectors complain that they must cover ever greater distances to reach areas in the forest where rattan is sufficiently mature to harvest. Despite the general awareness that immature canes bring lower prices, many collectors have begun to cut young shoots growing in areas closest to their riverside villages. Urban buyers and exporters confirm that immature canes comprise an increasing percentage of the overall supply.

The central government of Indonesia has drawn up a plan to regulate the trade and collection boom by "shortening" the trade networks and eliminating many of the trade links currently controlled by "middlemen." The official objectives of this plan are to increase the net profits of rattan collectors and to protect the supplies by restricting access. But, however well-intentioned, the proposal has not sufficiently considered local variations in environmental, socioeconomic, and cultural circumstances nor has it taken into account the differences in the real services provided by the various middlemen. The proposed system makes no provision for the performance of these services and makes no attempt to face the need to redefine property rights to a public access resource.

There are thus two purposes to this article. The first is to identify the events that have led to the "population explosion" of traders along the rivers and in the villages of East Kalimantan and to the lowering in the quality of the rattan. The second is to offer an alternative to the planned regulation, proposing instead the establishment of upriver rattan plantations and processing centers combined with locally specific systems for the definition of property rights, thereby offering a greater chance of averting a potential "tragedy of the commons."

\section{Evolution of the Collection and Trade System ${ }^{7}$}

Indonesian rattan was important on the world market as early as the mid-nineteenth century. ${ }^{8}$ At that time the Kutai Sultanate exacted taxes on all forest products transported out of the interior of eastern Borneo via the Mahakam river. ${ }^{9}$ The actual trade was conducted by the Buginese, and they exchanged imported goods such as salt, cloth, and tobacco for the rattan and other forest products collected by upriver peoples (various subgroups of Dayaks and some Kutais). Traders who sponsored forest collectors paid fees in kind (trade goods or rattan) to village

7. The project, "Interactions between People and Forests in East Kalimantan," which supported my research, was funded by the US Forest Service through a grant awarded to the East-West Center for US Man and Biosphere (MAB) program, "Consortium for the Study of Man's Relationship with the Global Environment." The project was carried out in association with the Indonesian MAB program and with the cooperation of Mulawarman University (Samarinda, East Kalimantan).

8. Harun Alrasyid, "Penanaman Rotan" (Paper presented to Discussion on Increasing Production Potential of Non-timber Forest Projects, Jakarta, July 10-12, 1980), p. 10 .

9. On the trading arrangements of the period, see, for example, Burhan Magenda, "East Kalimantan: The Fall of a Dependent Aristocracy," typescript (Ithaca: Cornell University, 1981), pp. 3-4; James F. Warren, "Trade, Raid, Slave: The Socioeconomic Pattern of the Sulu Zone, 1770-1898" (Ph.D. dissertation, Australian National University, 1975), pp. 24-26; and a number of nineteenth century articles on Borneo (appearing originally in the Singapore Chronicle), reproduced in $\mathrm{J}$. $\mathrm{H}$. Moor, Notices of the Indian Archipelago (London: CASS, 1967), pp. 29, 55, 67, 69, and 106. 
headmen and attempted to remain on good terms with these traditional leaders in order to be permitted continuous access to the rattan and forest products within their territory. ${ }^{10}$ Chinese and Banjarese traders joined the Buginese in the early twentieth century, ${ }^{11}$ but the system of paying fees to upriver leaders apparently remained the same.

In 1853 the Dutch made Samarinda the center of government for the Assistant Residency of East Borneo, and in 1900 the Sultan of Kutai ceded to them the right to tax imported trade goods and exported forest produce transported via the Mahakam. ${ }^{12}$ In exchange the sultan received a yearly allowance and 10 percent of the royalties the Dutch exacted from forest products, which was reduced to 5 percent by $1920 .{ }^{13}$

The Kutai Sultanate was not abolished until ten years after the Dutch transferred sovereignty to an independent Indonesia at the end of 1949 , but during those years the sultan no longer received royalties on the trade in forest products, which were sent instead to the central government. ${ }^{14}$ When East Kalimantan officially became a province of the Republic of Indonesia in $1957,{ }^{15}$ these taxes went directly to the provincial government. While recognizing traditional rights of indigenous people to those products of communally owned forest, the Basic Agrarian Law of $1960^{16}$ made no provision for traditional leaders' taxation of wild rattan and other forest products. ${ }^{17}$ As a result of this loss of sovereignty, and revenue, the local leaders had little incentive to continue their supervision of the extraction of forest products. A social "check" on the practice of ecologically sound harvesting procedures was thereby lost. Even the presence of Indonesian government forestry and army officials did not serve as such a check, for most of them came from Java or Bali and made little effort to learn about aspects of local traditional law.

A number of interrelated events have led to the currently burgeoning trade networks. Most of these events have been directly or indirectly related to improved

10. See also, Joseph A. Weinstock, "Land Tenure Practices of the Swidden Cultivators of Borneo" (Master's thesis, Cornell University, 1979), pp. 17-18, for a discussion of village territorial rights, including rights to secondary and primary forest areas, or "virgin jungle," as Weinstock calls it.

11. Magenda, "East Kalimantan," pp. 4, 42.

12. J. R. Wortman, "The Sultanate of Kutai Kalimantan Timur: A Sketch of the Traditional Political Structure," Borneo Research Bulletin, 3, no. 2 (December 1971), pp. 52-53. East Borneo was part of the Residency of South and East Borneo based in Banjarmasin.

13. Magenda, pp. $23,42,24$.

14. Ibid., p. 59 .

15. Ibid., p. 64 .

16. Weinstock, "Land Tenure Practices," pp. 97-99.

17. These statements all refer only to wild rattan. In East Kalimantan, rattan is cultivated most extensively in the southern district of Pasir. Informants also reported that there were rattan gardens in other parts of East Kalimantan, particularly in the Kutai district. Various systems of harvest and payment for harvest were reported, although extensive documentation has not yet been made of these. Weinstock reports on traditional planting techniques still in operation in Central Kalimantan (personal communication). Most statements in this paper concerning harvesting and trading rights refer to that rattan which grows wild in the forest. 
transportation and communications, changes in government priorities, the timber "boom," and lack of alternative cash-earning opportunities.

In 1959 the government banned the Chinese from upriver areas, and as a result the Chinese traders had to entrust their business operations in these regions to other Indonesians working for them. Within two or three years many of these non-Chinese traders bought the businesses. Soon afterwards, however, the government lifted the ban on Chinese traveling upriver, while continuing to restrict their right to live there, except under "special" circumstances. Consequently the Chinese and their former employees became competitors, each group developing their own complex networks of middlemen.

During the early 1960 s motorized river boats began to come into general use in the trading networks. Since they replaced the rowing boats manned by local crews of nine to twenty men, they reduced employment opportunities and also made river travel and transport of produce less time consuming and more efficient. At the same time, an increasing local demand for imported goods further stimulated the growth in traffic. Boom periods, during which certain forest products (such as crocodile skins and timber) were in high demand on the world market, brought an influx of "luxury" items, ranging from white sugar, ready-made cigarettes, and ready-to-wear clothing, to radios, motorcycles, and chainsaws. Since rattan collecting was one of the few means of earning the cash income needed to buy such items, increasing numbers participated in collection or small-scale trade, even though most collectors considered it a sideline to farming.

An explosion of general economic prosperity accompanied the beginning of the timber boom in the late $1960 \mathrm{~s} .{ }^{18}$ Without warning, in 1970 the central government restricted the general trade in logs and allocated commercial logging rights to largescale timber companies. Entrepreneurs who had bought boats or shops to profit from the logging boom now used them instead to deal in foodstuffs and trade goods or rattan and forest products, or both. Others were contracted by the timber companies to pull log rafts down river. Commercial logging activities also opened up formerly remote forest areas, with logging roads facilitating access to distant rattan-growing regions and increasing the rate at which the rattan could be harvested. During and following the manual logging and commercial timber boom (1967-78) many people from all over Indonesia flocked to East Kalimantan seeking employment. The indigenous population was also increasing naturally. During production or hiring lags in the timber industry, many of the unemployed turned to the collection or small-scale trade of wild rattan and other nontimber forest products.

In the mid- to late-1970s the world market demand for rattan rose while the proportion produced by the Philippines, the world's other major producer, declined. The Philippine government began to enforce existing laws more actively to protect their forest resources, including rattan, at the same time as the Japanese demand for Indonesian rattan was rising sharply. The culmination of these interacting factors was a burgeoning of once smooth-functioning trade networks. Large- and small-scale traders were seeking a finite resource: rattan.

To understand how this affected the society of East Kalimantan and its existing resources, it is necessary to analyze in greater detail how the river-trade networks actually operate.

18. See Chris Manning, "The Timber Boom with Special Reference to East Kalimantan," Bulletin of Indonesian Economic Studies, 7, no. 3 (November 1971), pp. 30-60 for further explanation of this important episode in the East Kalimantan logging industry. 


\section{The Trade Networks}

When in the early 1970s the government restricted the trade in logs to certain large companies, many timber buyers in the cities experienced huge losses from the credit they had extended upriver. Those who survived by switching to trading in minor forest products were naturally unwilling to extend credit to any traders not directly responsible to them, some agreeing to pay cash only on delivery of forest produce. As a result, numerous new arrangements for the allocation of credit have evolved along the network, most of them between participants of adjacent levels of trade.

Virtually anyone willing to invest the capital and take the risks has been able to enter the trade sphere. Collection points of various sizes are located in villages along, and at confluences of, the major rivers, the main trading artery being the Mahakam. Boats are supposed to be registered with the River Traffic Authority (LLASDF), which issues licenses allowing the vessels to carry passengers and some commercial cargo (taxi boats), or only commercial cargo (trade boats). In early 1980 , LLASDF officials estimated that only 50 percent of the river boats were legally registered, and blamed this administrative shortcoming on insufficient docking facilities and staff.

Possession of a boat is not a prerequisite for buying rattan. Some small-scale traders, or "river middlemen," purchase 100-kilogram sacks of sugar, cases of cigarettes, and drums of kerosene in Samarinda (or Tanjung Selor, Tarakan, or Balikpapan), and pay their passage by taxi boat to a particular upriver locale. At these points, their goods are sold on credit or for cash and rattan purchased from local collectors. The rattan is transported downriver by taxiboat, and the fee paid by the trader is determined by the weight of the rattan.

Middlemen trading at different points along the network must deal with the problem of environmental constraints on transportation and communication between forest collection sites and the urban buyers; the socioeconomic circumstances of, and relationships between, individuals involved in collection or trade activities; and/or the traditional controls on forest-product collection and trade, in effect before the current government-imposed regulations. These constraints have influenced the operations of traders in different parts of the systems and defined possible links throughout the riverine trade networks.

Figure A depicts the general situation, showing the possible trading links within the system. Local variations exist and are particularly common in the most isolated regions (where missionary planes sometimes replace boats) and in those areas where overland transport is possible. The following are the major participants in the trading network.

Village middlemen are traders living in particular villages or parts of the forest who act as liaison between forest collectors in those locales and village shopkeepers in larger villages or trade centers. As used here, "village middlemen" refers to traders who do not own stores but take trade goods on the behalf of a village shop, a trade boat, or a river middleman to distribute to collectors working in distant or isolated forest areas.

Village shopkeepers own shops in the villages and sell trade goods and foodstuffs to forest collectors and village middlemen. Goods may be sold for cash or credit; repayment of debts is generally in forest products of an equivalent cash value. The village shopkeeper sells the forest products he collects to large-scale river middlemen, trade boats, or directly to urban buyers. 


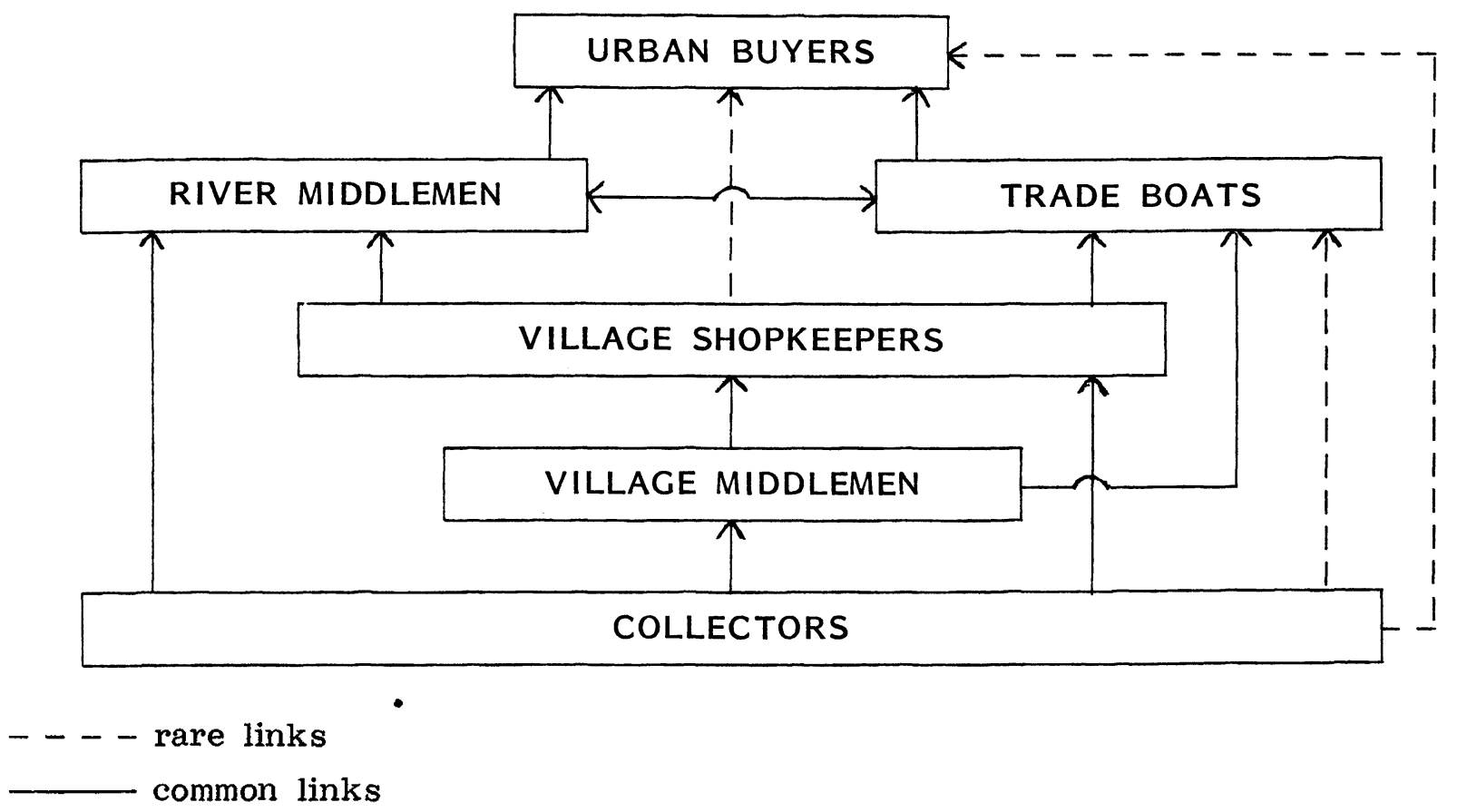

River middlemen are independent traders who do not own shops or boats but do buy forest products for cash or in exchange for basic supplies (such as kerosene, salt, sugar, coffee, tobacco, cigarettes, soap, etc.) from collectors, village middlemen, or village shopkeepers. To transport forest products to the city, these middlemen pay fees to taxi boats from collection points along major river systems. Depending on the size of their operation, some also hire motorized canoes to enter smaller tributaries in interior locales. River middlemen sell to either urban buyers or trade boats.

Trade boat owner/operators make regular upriver trips, bringing cash or trade goods to exchange for forest products. Wholesale trade boat operators deal almost exclusively with village shopkeepers, river middlemen, or retail trade boat operators (who function as "floating" village shopkeepers) and sell to urban buyers. Retail trade boat operators buy from village middlemen, small village shopkeepers, and, occasionally, from collectors. They sell to wholesale trade boat operators, river middlemen, or urban buyers.

Urban buyers are the last link in the trade networks in East Kalimantan and connect the network with foreign importers or exporters based in other Indonesian cities. They buy most of their forest products from trade boat operators or river middlemen, but sometimes purchase produce from other independent traders (village shopkeepers and others) or collectors who come to the urban area. From some of these towns and cities, the urban buyer himself deploys groups of collectors to gather forest produce.

Between the different levels of the network there are many kinds of credit arrangements. A village shopkeeper, for example, will extend goods on credit to a 
collector, who will generally pay off his debt with an equivalent amount of rattan. A trade boat operator, who has provided the shopkeeper with trade goods and foodstuffs and received regular payments for these wares, may be willing to lend the shopkeeper additional goods to be paid back in cash or, preferably, in rattan. Yet the trade boat operator would be reluctant to extend credit to a forest collector because this would impinge on the shopkeeper's territory and the trade boat operator would not be able to monitor the collector. During the two-to-four week period that the trade boat is away, the collector might sell his best rattan for cash to another trader or run away from the creditor altogether. The shopkeeper, on the other hand, is more likely to know each collector personally and is in a better position to make sure the collector does not sell to another shopkeeper or boat.

There is a clear distinction between traders who are interested in long-term security and those seeking merely short-term profit. In particular, traders who own some fixed capital--a boat, a shop, or relatively large quantities of durable goods in stock--appear to prefer the benefits of continued trade activity to those benefits gained by rapid liquidation of assets. But "ad-hoc river middlemen," that is, those who venture upriver only when rattan prices in the city are particularly high, have increased the level of competition among traders. These middlemen exploit their positions and try to make quick profits without concern for future transactions or maintaining relations with other traders and collectors. In general, their presence seems to have encouraged collectors to sell any quality of rattan for cash. The collector in debt to a local shopkeeper can get immediate cash from one of these ad-hoc middlemen and temporarily avoid paying his debt. Such occurrences have resulted in the adoption of a cash-only policy by village shopkeepers in many villages close to Samarinda.

Whether or not the government intervenes, rapid changes in the system are probably inevitable. As long as the timber companies continue to cut the forest, their employees will require the foodstuffs and trade goods provided by river traders. If no action is taken, access to rattan sources will remain unrestricted and become easier as timber companies cut roads into the forest. Labor from other islands will continue to be attracted to East Kalimantan by the prospect of working for the timber companies, while the companies may or may not continue their policies of contracting labor crews from other islands. Labor surpluses, including migrants who were never employed in the timber industry (but cannot afford to return home) and those indigenous and migrant workers who have been laid off by the companies, would have nowhere to seek income but in "traditional occupations." As we know, these options include collection or small-scale trade of minor forest products or petty trade in foodstuffs and household or agricultural goods. Thus, if present trends continue, the trade networks will expand even more, competition for forest products and customers will heighten, and the resources will become increasingly scarce.

\section{The Government Plan}

As mentioned above, the Indonesian government has proposed a plan to regulate the trade and collection of rattan. This plan was drawn up in $1980,{ }^{19}$ and presented at a national forestry conference held in March of that year, when representatives of the forestry division of the Department of Agriculture and trade-related government agencies and departments discussed its provisions with exporters of rattan and other nontimber forest products. In order to improve licensing systems,

19. Sek. Ditjen. Kehutanan, "Perijinan Pemungutan Hasil Hutan Non Kayu," mimeo. (Jakarta, 1980). 
harvesting techniques, and the processing of nontimber forest products (especially rattan), the plan called for implementation of the 1974 decree of the Minister of Agriculture, ${ }^{20}$ providing for permits, or HPHH (Hak Pemungutan Hasil Hutan, Licenses to Harvest Forest Produce) for nontimber forest products to be issued to specific urban buyers. These licenses would designate the varieties and quantities of rattan that buyers would be permitted to harvest in a specific locale for up to six months. Although the details of administering the HPHH were not included in the 1980 proposal, there was a general consensus at the March conference that the licensed urban buyer would be linked directly to the KUD (Koperasi Unit Desa, Village Cooperative Units), the cooperatives established and controlled by the government to handle rice marketing, at either the village or the subdistrict level. The plan strongly implied that the buyer would be expected to advance credit to the KUD prior to receiving the rattan. These advances would then support the collectors while they gathered rattan in the forest. Details not clarified in the plan were who would bear its initial implementation costs, whether the rattan would be transported by government boat, by the buyer's boat (if he had one), or by other means, and who would set the prices at either end of the transaction.

This plan can be viewed as a shift from private to public entrepreneurship. Such public management of rattan resources would allegedly prevent excessive overexploitation, in that elimination of middlemen would not only increase the collector's profits but would also relieve some of the pressure on the rattan resources. Yet, there are many disadvantages to the plan. In presenting it, the government argued that public regulation was needed to curb the "monopoly power" of the middlemen and traders. While Chinese export firms do monopolize the export of rattan from East Kalimantan, middlemen in the internal marketing networks in fact often perform real services for the collectors and traders with whom they work. ${ }^{21}$ Some traders, for example, pay hospitalization or medicine costs for their regular suppliers and their families; others provide labor opportunities when trade-related jobs are scarce. The present system also guards the collector against financial loss in the wake of unexpected environmental disasters (flooding, droughts) and in some ways protects him against market fluctuations. Certain of these transportation and marketing risks are now absorbed by the middlemen. For example, if rattan becomes wet enroute to the city via the river, a trader having a regular relationship with a higher-level buyer need not absorb the loss all by himself--his regular buyer

20. Menteri Pertanian Republik Indonesia, Surat Keputusan Menteri Pertanian, official document no. $749 / \mathrm{kpts} / \mathrm{um} / 12 / 1974$.

21. On the role of middlemen, see also Donald K. Emmerson, Rethinking Artisanal Fisheries Development: Western Concepts, Asian Experiences, World Bank Staff Working Paper No. 423 (Washington, D.C.: The World Bank, October 1980) ; Raymond Firth, Malay Fishermen: Their Personal Economy, 2nd ed. rev. (Hamden, Conn.: Archon, 1966); Alice G. Dewey, Peasant Marketing in Java (New York: Glencoe Free Press, 1962); Ian R. Smith, "A Research Framework for Traditional Fisheries" (Manila: ICLARM [International Center for Living Aquatic Resources Management], 1979); Nancy Lee Peluso, "Survival Strategies of Rural Women Traders or a Woman's Place is in the Market: Four Case Studies from Northwestern Sleman in the Special Region of Yogyakarta" (Paper presented to International Labour Office Jakarta for use by the Department of Manpower, Jakarta, 1980). Cf. Clifton Wharton, "Marketing, Merchandising and Moneylending: A Note on Middleman Monopsony in Malaya" (Agricultural Development Council reprint, 1962); R. C. Stirrat, "Fish to Market: Traders in Rural Sri Lanka," South Asia Review, 7, no. 1 (1973), pp. 189-207, and others who regard middlemen in general as "rapacious monopsonists." 
may share it by paying the trade boat operator at or just above his cost. In the planned cooperatives, no such safeguards as yet exist; and the likelihood is high that excess costs would have to be borne by the collectors alone.

Furthermore, by requiring participation in a government cooperative, the "monopoly power" of the middleman would be replaced by a much stronger monopoly. The trader-provider services, the varied credit schemes, and the leverage of the collectors and small-scale traders in the credit market would be reduced. Market participants would not be free to determine when to collect or trade; the part-time nature and flexibility characteristic of nontimber forest products' collection and trade might disappear as people felt impelled to repay loans quickly for fear of government reprisal. Such feelings could result in more people collecting rattan full-time, or at least more frequently than now, further straining the resources.

By rendering private lending illegal (in the interests of the cooperative system), alternative sources of credit would become more expensive (because they would be considered "black market" and carry greater risk). The poorest borrowers would be the least likely to have the means for repayment; the plan could thus create more problems than solutions.

The government proposal implies that urban buyers would extend credit to upriver villages via the government cooperative, the KUD. Two obvious disadvantages to such a proposal, are that in most of the riverine villages covered by this research, KUDs have not been established, and within the KUD structure, few incentives exist for good service. Furthermore, in East Kalimantan, government accounting is notoriously costly and inaccurate--often because of the limited facilities as one proceeds further upriver. Greater burdens in terms of staffing and responsibilities would be placed on the KUD if both rice marketing and rattan production and trade were in their jurisdiction. It is true that the prices of goods and credit increase with each middleman handling them, but it is also true that the salaries of government officials operating the networks would involve similar costs, and there is no reason to believe that public middlemen would be less inclined than private middlemen to extract "fees" or "taxes" out of this credit (in cash or in kind). Many KUDs which handle rice marketing in Java and other parts of Indonesia have reported problems with management of funds. Often, the rice purchased by the KUD cannot be sold competitively and profitably. In addition, if the government were to replace the middlemen's roles, its officials would still lack the kind of experience and contacts needed to acquire timely information about the supply and demand of rattan in both interior source areas and external markets. Private entrepreneurs in the cities would still control external marketing information.

Viewed from the other end of the network, the need for checks in the system of credit extension makes it unlikely that urban buyers would be receptive to the government's plan for them to extend credit directly to specific rattan-collecting villages, 100,300 , or 600 kilometers upriver. The current system allows the risks in such credit arrangements to be spread out over a number of stages of trade (i.e., the credit system consists of a series of local loans between people at adjacent levels of trade). As mentioned above, since suffering great losses in timber speculation in the early $1970 \mathrm{~s}$, downriver traders have become discriminating in determining who may borrow money or goods. Those who will still extend credit do so only to close associates, and long-term loans are far preferred to long-distance loans. Credit is granted those traders who remain loyal to individual buyers or those who make reliable repayments on their loans. Mutual trust is a key element of these credit ties and such trust is based on mutual understanding. The cultural gap between the large-scale rattan buyers in the cities and the upriver village rattan 
collectors makes trust and understanding nearly impossible between them. The government plan, therefore, would eliminate the localized and personal nature of credit extension without any consideration of the social and environmental constraints inherent in their "direct" long-distance loans between producers and final domestic buyers.

\section{Alternative Means of Management} of Rattan Collection and Trade

In proposing an alternative to the government's plan, it is necessary to consider two levels of the problem. First, the need to limit access to the supplies of rattan so that the resources are not overexploited; and second, the need to ensure that changes in the trading network do not adversely affect the local society and that those who have previously participated at the various levels of the river-trade network are provided with alternative sources of income.

With regard to the first of these problems, one method often proposed for limiting access to a natural resource is allocation of private property rights to particular individuals, who are likely to manage more efficiently and profitably the resources on their land. Apart from the difficulties involved in deciding to whom and how to allocate the land, such an alternative would seem impractical and undesirable in the case of East Kalimantan's rattan-growing areas; not only would it isolate many of the people from a major source of livelihood, and overturn the existing community structure, but it would also run the risk of a new owner at some stage maximizing his own profits by stripping the land of the rattan, selling it, and reinvesting his profits in a more lucrative enterprise.

A more practical alternative would be to design a system of group ownership, whereby benefits of increased production would be more widely distributed. To be effective, such a system would need to be based on local social and economic cooperative structures rather than on a superimposed hypothetical plan designed by "outside experts" lacking understanding of indigenous networks and institutions. Very small groups would be preferable to subdistrict organizations to simplify management and decision-making procedures. To avoid overexploitation of the rattan on the property, it would be necessary to build in a number of incentives to encourage the joint owners to conserve the area under their jurisdiction. For example, permission to harvest rattan or participate in the rattan trade could be contingent on compliance with sustained yield management procedures.

Under any kind of management, an incentive system requires an appropriate procedure for rule enforcement. Local social sanctions on violators or potential violators, in combination with or prior to governmental sanctions, would be the ideal arrangement for control of resource use. Moreover, the opinions and ideas of collectors and traders in regard to problems anticipated in designing management groups or other systems are crucial to the success of the endeavor. Continued feedback from participating collectors and traders could lead to development of locally relevant management schemes which would improve the sustained yield of rattan. As Thomson has pointed out, such improvements could justify the high decision-making costs of organizing user groups and coordinating their participation in planning. ${ }^{22}$

22. James T. Thomson, "Guesselbodi Forest: Alternative Frameworks for Sustained Yield Management" (Report prepared for Niger Forestry and Land Use Planning, Maryland, 1981), p. 48. 
In recent years. particularly since the arrival of foreign timber companies, local people have come to feel their interests are not given sufficient consideration. Not only have they reported hostile confrontations with timber company personnel, they have also been discouraged by the government's regulations drastically limiting the villagers' rights to harvest timber. If the local people were allowed or encouraged to participate in the design and implementation of rattan-harvest management schemes, they might be more eager to enforce regulation of harvesting procedures.

Again, the major cost of limiting access to any common property resource is the exclusion of potential entrants (a very expensive cost in a society where incomegenerating opportunities are scarce and people seeking employment are many). But as Smith has pointed out limited resources of an "open access" nature do not themselves lead to low income unless entry to the resource is unchecked. ${ }^{23}$

The second major step to alleviate the pressure on the system would be to create alternative employment opportunities in the vicinities of rattan trade and collection centers. Group property rights could be allocated as discussed above, and a version of the present trade system could be allowed to continue, although under much less pressure of potential expansion.

Rather than eliminating the functions of all middlemen, viable income-producing alternatives in the vicinity could be offered. The ideal types of enterprises would be those that could increase the quantity and improve the quality of rattan--such as rattan plantations and first-stage rattan processing centers. In many villages in the districts of Kutai and Pasir, farmers traditionally planted rattan in their dry fields (ladang) before letting them go to fallow. During the seven to ten years that elapsed before the rattan could be harvested for the first time ${ }^{24}$ they cultivated rice and vegetables in other, newly cleared fields. In some areas, planting rattan in dry fields is still common practice, but not in others. Yet the precedent for rattan plantations, at least on a small scale, has been set.

Former middlemen could be employed in processing centers as receivers, checkers, weighers, graders, supervisors, or processors. Because of their current skills, costs of further training would be minimal. Incorporating them would avoid the individual costs and resentful feelings that might result if they are excluded. The application of their skills, the total revenues earned from their work, and the avoidance of deprivation costs to them, constitute come of the social benefits involved in such a plan.

An example of the potential success of first-stage processing centers is what has developed in the Middle Mahakam village of Long Hubung. Established in 1978 by a local man (of the Busang Dayak ethnic group), the center employs between eighty and two hundred people at a time who clean, sun-dry, sulfur-treat, pack,

23. Ian R. Smith, "A Research Framework for Traditional Fisheries" (Manila:

ICLARM [International Center for Living Aquatic Resources Management], 1979), p. 9.

24. The time until the first harvest varies according to the variety of rattan. Traditionally, 10-20 percent of the stems in a clump of Calamus caesius would be cut each year, with the remainder left to grow for up to five to ten years longer. Stems of Calamus trachycoleus, which does not grow in clumps, would be cut successively further back into the forest. See John Dransfeld, A Manual of the Rattans of the Malay Peninsula, Malayan Forest Report no. 29 (Kuala Lumpur: Ministry of Primary Industries, 1979), and Burkill, Dictionary of the Economic Products of the Malay Peninsula, pp. 1904-5, for more detailed information on the natural history of rattans. 
and load rattan. Much of the rattan has been brought by canoe or raft from upriver locales through four sets of rapids which render the river impassable for trade boats. His success is evident not only in his thriving rattan business, but also in the way it has stimulated development in Long Hubung. A new school (the only junior high school in the area), a village meeting hall, numerous houses, a dormitory for school children whose parents live above the rapids, and his three trade boats are a few of the tangible proofs that such a venture can succeed and have considerable multiplier effects. Indirect benefits include the increased demand for services by the processing center's employees.

Other foreseeable advantages of establishing upriver processing centers and plantations include control of the quality of harvested rattan, better preparation of rattan before shipment, and upgrading the trade network.

These processing centers could refuse poor-quality canes, forcing traders to be more particular about the quality of rattan they accept, and collectors to cut more selectively. Complete drying and chemical treatment of rattan in the centers would protect it and ensure that more high and less "reject" quality would reach the city, thus increasing total revenues. Finally, the current trade system--which has adapted to environmental and market constraints--could operate more efficiently.

One potential disadvantage of this option is the competition it could stimulate between additional migrant laborers attracted to the area and the local people. Production and treatment centers should be designed with a view to lessening such potential competition. Moreover, if property rights to the rattan resources were already allocated, and enforcement measures taken, the risk of overexploitation of the resources would be minimal. On the other hand, incoming migrants might meet the growing demand for services among local workers.

The seven-to-ten year waiting period before the newly planted rattan can be harvested might also be perceived as a disadvantage. For most households, however, rattan collection is a secondary occupation which may be put aside at points in the agricultural cycle when labor requirements are high. When primary or secondary forest is being cleared and burned, for example, much of the household's male labor is required. Such labor allocation patterns do not prevent a regular trader from acquiring rattan throughout the year. The timing of agricultural activities generally is consistent within each village, yet the trader is still able to obtain rattan from that village--although in smaller quantities. The reason is that the individual household still requires cash, and one or more household members, men or women, ${ }^{25}$ may collect rattan, while the others tend the fields. Here again, locally relevant knowledge is an important "skill" possessed by the trader or middleman. When and how labor can be mobilized to meet quotas and deadlines is crucial information. ${ }^{26}$

If the world demand for rattan drops, it would be possible to leave the rattan growing until demand and price increase. In fact, leaving the rattan to grow for longer periods may result in larger harvests. Informants in the southwest part of East Kalimantan report a rattan plant cut for the first time fifteen years after planting produces three times as much as a plant first cut seven years after planting. ${ }^{27}$

25. The participation of women tends to vary among villages, ethnic groups, seasons, or periods of economic prosperity and scarcity.

26. Contracts with overseas buyers are generally for a quantity of rattan to be delivered in the course of a year, thus the Indonesian exporter is less pressured by seasonal constraints on the supply.

27. Joseph Weinstock, personal communication (1982) 
Further research on the frequency of this type of occurrence would be of great value in planning rattan plantations.

The long-range benefits--in terms of continued employment opportunities, multiplier effects in the communities, relief of the pressure on the current trade networks (if the plantations are properly planned), and the improved quality of the rattan sent downriver--significantly outweigh the disadvantages. During the seven-to-ten year transition between planting and the first harvest, it will be essential to monitor the activities of timber companies in the province. Depending on their stages of production/timber harvest, they may be hiring or laying off workers--consequently, many locals and recent migrants may be seasonally or permanently unemployed. Some of these could be hired in the construction of a processing center (ideally, within this interim period) and in the initial process stages. If such employment opportunities are not available and access to the resources is not restricted, surplus labor will strain the supply of rattan rather than work in a direction to upgrade it.

\section{Summary and Conclusion}

This paper has explored the question of how much government control of rattan collection and trade is appropriate for East Kalimantan. ${ }^{28}$ In the past, social controls helped limit the supply, and the demand for rattan was apparently much lower than it is at present. However, with the disappearance of traditional controls, the trade networks have expanded, the world demand for rattan has risen, and the competition for the limited supply has increased while replanting has been minimal.

If no action is taken, a "tragedy of the commons" may play itself out, and both present and future generations will suffer from the lack of good rattan. As discussed above, the government's proposal to avert such an outcome by regulating the collection, purchase, and sale of rattan through government-controlled "cooperatives," is unlikely to be effective. It is not designed to channel credit efficiently from downriver to upriver, and the costs of implementing it are likely to be borne indirectly or directly by the collectors themselves.

At this point, a return to the traditional system of tribute is also impossible. Perhaps the most valuable role the government could play in the rattan-growing areas would be to develop additional, appropriate income-earning opportunities, that would relieve pressure on the trade networks and the forest resources as the primary source of cash income. If enterprises such as rattan plantations and firststage processing centers were established, these would increase the quantity and improve the quality of rattan, would absorb more labor, and would raise the opportunity wages of collectors. Processing rattan before shipment downriver would raise the upriver prices and funnel a greater percentage of profits to participants in the initial stages of the trade networks. Similarly, classifying rattan upriver according to internationally accepted grading standards would increase the value added in these initial stages. The availability of temporary or part-time job oppor-

28. The question is not a new one for Indonesia. In late nineteenth and early twentieth century Java, controversy arose between private entrepreneurs and the Dutch government over the cutting of the teak forests. By 1913, State management had superseded private enterprise and efforts were made to conserve jungle woods. Such efforts did not receive much attention in the "Outer Provinces," however, particularly Borneo, because of the almost nominal administration there. See J. S. Furnivall, Netherlands India: A Study in Plural Economy (New York: Macmillan, 1944), pp. 176, 201-2, 222, 325. 
tunities such as these would also allow local farmers the time to cultivate their fields; seasonal fluctuations in both the labor supply and the demand for the rattan require a flexible plan. Restricting entry into the commons--the forest--as suggested earlier, demands that the people be provided with alternative employment opportunities to supply their increasing cash needs.

In the long run, a plan of action combining all or some of the elements described above will improve vertical linkages (resource--collector--distributors) and horizontal linkages (between plantations--processing centers--ownership groups--and other rural institutions). Such a holistic approach to rural sector development views the solution as well as the problem as diverse wholes composed of interacting and interdependent parts. 